\title{
PROBLEMS WITH PRAGMATIC APPROACHES TO SETTING A MORAL SCOPE
}

\author{
JAMES HENDERSON \\ (University of Pittsburgh-Titusville - United States)
}

\begin{abstract}
In Towards Justice and Virtue and "Distant Strangers, Moral Standing, and State Boundaries," Onora O'Neill argues that questions of the form "To whom is one obliged to accord ethical treatment?" may be decided based purely on the actions of the agent in question. In particular, she claims that metaphysical accounts of personhood are not necessary to set a moral scope and that such accounts have failed in any case. While there can be no doubt that no account of personhood has achieved unanimous acceptance, her account is found wanting based on the observation that actions are not sufficient to separate all of those within our moral scope from all of those outside it. Indeed, clear examples of entities not deserving ethical treatment fall under her umbrella of protection. Solving this problem requires just what she seeks to exclude from her theory - an account of personhood. By paper's end, it should be clear that any theory based purely on the actions of agents will be insufficient to separate all the ethical wheat from chaff.
\end{abstract}

Keywords: Ethical standing, ethical scope, Onora O’Neill, pragmatic construction

\section{Introduction}

Every atrocity, every violation, and every misuse of a person or a group of people, reported or unreported, cries out for a general scheme to set a moral scope that may be used to determine who is entitled to ethical treatment from another agent. It is clear that there is no theoretical account of personhood that has achieved canonical status with a majority of philosophers or the population at large, and, worse still, offenders may hide behind such accounts, claiming that their theory leaves their victims beyond the pale of moral consideration; they are then free to conclude that they are doing nothing wrong even when there are flagrant transgressions of civilized behavior being committed. Ethical pragmatists claim that their action-based approaches to setting a moral scope can give a universal account and even use the actions of oppressors to put the lie to claims of innocence, something that theoretical schemes cannot do. If true, this would unify the approach to setting a moral scope and break the impasse formed when different groups, often cynically, claim to employ different criteria to establish who has rights and when those rights are violated. Unfortunately, pragmatic programs do not seem to be able to deliver on their promises. The present work concentrates on Onora O'Neill's account but it should be clear by the end that any account based purely on actions will be problematic with respect to dealing with the issues raised, given that, among other things, it is often the case that our actions are indistinguishable in cases both of ethical import and insignificance.

In Towards Justice and Virtue and "Distant Strangers, Moral Standing, and State 
Boundaries," O'Neill argues that theoretical attempts to answer questions of the form "Who deserves moral treatment?" have been unsuccessful. Indeed, she says that "[w]ithout a more explicit vindication of... the necessary metaphysics, it may be quite impossible [for universalists] to establish necessary and sufficient conditions for qualifying as [one deserving of justice or having moral standing]." Similarly, particularist arguments are "no more convincing" in that those we do not care about for reasons of blood, nationality, love, friendship, or just proximity would have no right to just or ethical treatment from us on those accounts. ${ }^{2}$

It is in the face of these failures that O'Neill puts forth her program for constructing the scope of ethical concern in a pragmatic fashion. Rather than trying to establish a metaphysics of the person, O'Neill uses a three-pronged, practical basis for setting an ethical scope. Interestingly, but perhaps not surprisingly, her account founders on the same rocks as the others when it comes down to a certain class of difficult cases. It is not fatal to her version of the story if one-hundred-percent agreement is not reached regarding cases of, say, abortion or euthanasia, but the shortcomings of O'Neill's theory will be seen to be much more thoroughgoing than those involved with applications in one case or another. At the heart of O'Neill's difficulties lies the claim that she need not supply a definition of what it means to be an agent, or, in her terms, an other. It will be shown that without such a definition her account is plagued with problems that her prima facie intuitively pleasing program cannot solve.

\section{O’Neill's Program}

For O'Neill, the scope of ethics is set by three assumptions that she terms plurality, connection, and finitude. The assumption of plurality is one made by all who do not consider themselves to be brains in vats. That is, when Smith goes through life accepting the notion that there are others "out there" in the world, he is making the assumption of plurality. When this assumption is adopted, an agent's activity will reflect the adoption. Naturally, specific assumptions about others vary widely depending on how these others might be affected by the agent's activities and their capacity to respond to these activities.

Some activity assumes identifiable others who can... respond in complex, intelligent, immediate, and focused ways; at the other end of the spectrum, some activity assumes only that unspecified others could be affected or react minimally to the remote results of that activity. ${ }^{3}$

On the other hand, "[p]lurality is not assumed in activity that takes it that no others can be affected or respond, whether directly or indirectly." 
It is important to note that activity need not assume others will be affected or will respond for it to reflect an assumption of plurality. Movies are produced, books are written, and music is composed even though the possibility exists that they will never be seen, read, or heard. Others might see, read, or hear these movies, books, or music because they have the capacity to do so, even though sometimes this capacity is unrealized. Boys in high school telephone their girlfriends to ask them to go to the prom knowing full well that it may be the case that no one is home; castaways build signal fires to attract rescuers fully aware that these measures may be in vain.

While much of our activity does not involve an assumption of plurality, this assumption is rarely rejected generally - we don't take seriously the Cartesian notion that a demon is trying to trick us into believing that we are surrounded by "people" when we "go to the office." "Shall I hit the snooze button or rise now?" and "Will my first draft be written in pen or pencil?" are questions that may be offhandedly answered, but "Should I help the elderly lady cross the busy street?" is not of this type. Similarly, a Crest-or-Colgate dilemma may be handled in a cavalier fashion that is inappropriate in considerations of whether it would be a good idea to speed one's automobile through a busy school zone. Since plurality is so widely accepted, then, it forms only a part of O'Neill's analysis of ethical scope.

An assumption of connection is made when an individual assumes his actions can have an effect on the other's life. The world is full of causal connections and patterns: Gravity causes rocks to fall, smoking causes cancer, and sex causes babies; fall follows summer, night follows day, and thunder follows lightning. Within this vast causal network are the connections between others. Some of our activities are private; that is, we may reasonably assume that either our doing X or our not doing $\mathrm{X}$ will make no difference to anyone but ourselves. Alternatively, sometimes our actions, or ripple effects therefrom, have profound effects of on others. When actions are guided even in part by concerns regarding effects on others, an assumption of connection has been made. For instance, Smith assumes that Jones, his neighbor, may be affected by his music. In such a case, he may turn down his stereo after 9:00 pm to avoid disturbing her. It makes no difference if Jones is out for the evening, on vacation, or even temporarily deaf. Smith believes his stereo may distract Jones from her work or keep her awake, so he acts accordingly. It is Smith's action that demonstrates his assumption that he and Jones are connected. On the other hand, Smith may make no assumption of connection with inhabitants of a planet in a distant galaxy, so his actions would not serve to show he feels he has any effect on them whatsoever. Now, the distinction between making and not making this assumption need not be based on distance. Smith may or may not adjust his behavior based on his beliefs regarding connection with people living across town, on the other side of the globe, or, with respect to time, those not yet born or those who lived one thousand years ago. Smith may also fail to assume connection with a group of others if he is unaware of their existence (O'Neill gives the example of inhabitants of Anglo-Saxon England and T'ang Dynasty China, two groups, 
though contemporaries, completely oblivious of one another). In such a situation it makes no sense to say Smith acts unethically towards a group of which he is unaware; he can't be held accountable for his actions with respect to a group he has no reason to expect to even exist. Significantly, if Smith falsely assumes there is no connection with, say, Johnson, who lives down the block, he may inadvertently act in a way distressing to Johnson, who will ask Smith to, say, stop driving his car so fast up and down the street. That is, false assumptions regarding connection (or, as it turns out, plurality or finitude) are corrigible.

Finally, an assumption of finitude is one in which a recognition of the finite capacities and powers of others is made. This seems to be done automatically when one assumes one's actions will have at least a small effect on another. Particularly easy examples of this are assumptions of finite size or longevity of particular, identifiable others. Again, if actions are in any way determined by concerns regarding others not being impervious to results of activity, then an assumption of finitude has been adopted.

According to O'Neill, if Smith makes all three assumptions of another, then that other falls into Smith's ethical scope, and he may not revoke ethical treatment from this person without reason. There is very good reason to think O'Neill might be onto something important here. Recall that whether these assumptions are made is not determined by what Smith says but, rather, what he does. Humans, as a group, act in ways which are as closely linked as possible to accurate views of the world to avoid pain, injury, or other misfortune, whereas they may tell outrageous lies for the very same reasons. Since O'Neill's system is based on assumptions that determine actions rather than having a basis on mere words, there is every reason to think that it will yield solid results.

This optimism is shown to be warranted by O'Neill's dealings with problems provided by groups like the Nazis. Nazis claimed that their victims had no moral standing, but their actions indicated otherwise. O'Neill argues that everything the Nazis did to their victims betrays the fact that they considered them "intelligent, literate, foresighted agents... capable of complex mental and physical suffering." ${ }^{5}$ To counter O'Neill, it may be argued that many of the things the Nazis did were done to cover their tracks and hide the magnitude of their crimes. The burning and burying of bodies, the destruction of records in the death camps, and the laundering of money in Swiss banks all seem to support this thesis. However, some of their deeds have motivations that do not seem to fall into these self-serving categories. Jews, gypsies, and other "enemies of the state" were told they were being relocated to housing in the East as they were boarding trains to death camps. One can only imagine that Prussian cows were not told they were being relocated to Polish grazing land when they were shipped off to slaughterhouses and that Bavarian chickens were not misled as to their fate in army kitchens. This is all with good reason - cows and chickens are not the sorts of things that need to be deceived in order that they may be kept under control. Jehovah's Witnesses and homosexuals, on the other hand, are quite naturally given to panic when they are told they are 
to be systematically exterminated. One might wonder why the Nazis would have bothered to lie to these groups if they (their victims) were incapable of even basic human mental ability. Indeed, "[a]ll of the subterfuge, the administrative formalities of deportation, the rhetoric of belittlement, the techniques of control make sense only on the assumption that the victims were indeed seen as intelligent agents and vulnerable subjects." ${ }^{\prime}$

Note here that O'Neill has not simply informed us that the victims of the Nazis were human, which would have been completely unnecessary in any event, but rather she has cut right through all the Aryan rhetoric about the victims being "not like us" and demonstrated that the Nazis knew that they and their victims were cut from the same human cloth. Without an appeal to the actions taken by the Nazis, the impasse of the Nazis swearing their victims were subhuman and our cries to the contrary could not have been overcome. As it stands, O'Neill has put the lie to their protestations in a rather striking manner. The old saw "Actions speak louder than words" rings especially true in this case, and it is O'Neill's position that it will always ring true.

\section{Test Cases}

To see the difficulties in O'Neill's account, it will be helpful to look at different applications of it in concrete situations. If a problem emerges repeatedly, it may be possible to generalize from individual instantiations of objectionable material to a more comprehensive diagnosis of what is wrong. It will be profitable to begin with a concern raised in both Towards Justice and "Distant Strangers": burglars.

Smith recognizes the existence of burglars, people who don't live in his home but might break in to steal his possessions. As he would be negatively affected by this, he takes precautions to keep it from happening or to lessen the blow if it does. Smith first organizes a neighborhood watch program to protect all the houses on his block. Next, he puts new locks on all his doors and bars on his windows. He has a security system placed in the house, and he insures all his valuables. He even buys a big doberman guard dog named Satan to make his home less attractive to thieves. In taking these actions, Smith demonstrates that he has made the assumptions of plurality, connection, and finitude toward the burglars in his area. After all, he accepts that they are out there, that they may steal his things, and that their objectives might be thwarted by actions he takes. Presumably, then, these burglars are within Smith's ethical scope.

This seems perfectly natural, and as these burglars have moral standing for Smith, there are some things he shouldn't do to protect his house. For instance, applying a deadly contact poison to all the outside doorknobs of his house appears to be going too far to stop burglars. Pits with bamboo stakes and Burmese tiger traps would also strike most people as excessive security 
measures. Burglars are people, too, and while they may deserve hefty prison sentences, none of his neighbors wants Smith putting the heads of captured burglars on spikes outside his house as a warning to other would-be miscreants that it would be wiser to move on to another part of town. Taking these steps would ignore the ethical value of the lives of burglars - ethical value that Smith recognized when he began taking action to safeguard his home to begin with.

Jones is much more concerned with house fires than she is with burglars. In fact, she is so concerned about a fire breaking out in her home that she had a sprinkler system installed. She has two fire extinguishers in her house and checks them regularly, she has her children practice using their fire escape routes once a month to make sure they'll be safe in the event of a blaze, and she bought fire insurance for all her belongings. The fire department's phone number is placed prominently next to her kitchen telephone, and she even studied her son's Boy Scout Handbook to learn the best way to put out each different kind of fire.

Jones clearly recognizes that there are such things as fires that can break out in her home. She knows that they can have disastrous effects on her and that her actions can greatly affect a fire if it is caught in a sufficiently early stage - its power has limits. Is it the case, then, that fires fall within Jones' ethical scope? Does she owe a house fire moral consideration? If Jones has made assumptions of plurality, connection, and finitude with respect to fire, why is it so obvious that fire has no ethical standing for her? The answer is, of course, that no assumption of plurality has been made. It is a very different thing to say "That is something other than what I am" than it is to say "That is an other," where 'other' in the latter sense carries the meaning of 'agent.' O'Neill claims she doesn't have to define what she means by 'other': "A practical way of fixing the scope of ethical consideration need not supply a complete account of who or what counts as an agent.... It must, however, provide at least a procedure by which agents can work out to whom (or what) they must accord ethical standing." accord ethical standing' means 'a procedure to identify an other.' This is precisely what O'Neill does not want. She wants the ethical scope to be defined by agents' actions, but the actions toward burglars and fires in the above two examples are the same; it is our attitudes towards burglars and fires which differ.

There are a couple of easy solutions which one may try on O'Neill's behalf. One could say that there are actions homeowners would not take to stop burglars, but there are no corresponding actions they wouldn't take to stop a fire. This, however, is no solution. It may be said that this is evidence of unethical treatment of fire. Recall that the actions of Smith and Jones demonstrated that assumptions of plurality, connection, and finitude were made with respect to burglars and fires, respectively. The differing actions we are discussing here regard the treatment of burglars and fires after these assumptions have been made, and according to O'Neill (that is to say, based on actions already taken) they should not differ. If one takes the position that there are 
things we wouldn't do to put out a fire - surely true - then it is easily seen that this is based not on a loving attitude toward fire but rather on an impulse to minimize damage done by the fire and the actions taken by those who put it out.

A second possible escape - a second way to deny an assumption of plurality has been made - is explicitly mentioned by O'Neill: “[T] he capacities which seem important to full agency are... uncontroversially absent in sticks and stones." Presumably these capacities are also absent in fires. What is it about agents and sticks and stones that make them so uncontroversially different? A denial of agency for O'Neill cannot come from different attitudes or after-the-fact actions regarding sticks and stones and chimpanzees and people; it must be demonstrated that chimpanzees and people have capacities not present in sticks and stones. This is almost too easy. O'Neill points out that philosophers have long felt that there are "specific capacities for independent life" which may bear on the issue of agency. ${ }^{9}$ We can simply point out that sticks and stones (and fires) are not alive and that chimpanzees and people are. This could explain why a denial of an assumption of plurality with respect to fire is acceptable: Humans act differently with regard to living and non-living things.

\section{Other Cases}

It will be instructive to continue to push the envelope with regard to life or lack thereof as an acceptable criterion for denying ethical standing. That is, to see if this is really what is needed, the discussion must go where the lines are blurred.

Johnson is very concerned about viruses. In the cold and flu season he refrains from shaking hands with people, and he washes his own hands frequently. To avoid more serious viruses, he will engage only in monogamous relationships, and then only after he has exchanged HIV test results with his prospective partners. He uses no intravenous drugs, and he stores his own blood at the hospital in case of an emergency - this way he doesn't have to take a chance that a tainted pint of blood will find its way into his veins from the blood supply. Lastly, he has catastrophic health insurance coverage just in case his precautions fail to protect him completely. His actions dictate that he has made assumptions of plurality, connection, and finitude with respect to viruses. He knows that viruses are out in the world, he knows that they may make him sick or even kill him if they infect him, and he knows that there are things he can do to keep them from infecting him. Given all this, it is still counter-intuitive in the extreme to think that Johnson owes any moral consideration at all to viruses which may or may not infect him. In this light, we may try to deny that he has made an assumption of plurality with respect to viruses based on the fact that viruses are not alive. This, however, presents a problem: there is no real consensus in the biomedical community as to the 
life-status of viruses. Viruses, by all accounts, are neither considered to be living nor non-living organisms. How then should one justify the obviously proper conclusion that Johnson does not owe viruses moral consideration? It would be ludicrous to assume that such a conclusion could be reached on the basis that viruses are terribly small. On this reading, sumo wrestlers would be afforded greater respect than jockeys based on their enormous girth. It cannot be based on the life status of viruses because those in the scientific establishment don't know what that status is. An argument that we can deny ethical standing to objects whose life status is unknown for the very reason that their life status is unknown fails on several counts. First, it seems at the very least awkward that human failings in the sphere of science should justify moral and ethical decisions to treat possibly living organisms in a way that is less than moral. Our definitions of life, arrived at largely by convention and convenience, surely do not give us the right to deny or revoke ethical treatment of other beings. In such a case it seems agents should err on the side of ethical treatment. Further, a nearly identical scenario as the one above could be drawn up for bacteria rather than viruses. Bacteria are certainly alive, but it would be madness to accord them moral consideration. If similar problems all the way up the evolutionary ladder are to be avoided (do plants deserve ethical treatment? how about insects?), some kind of criterion for separating the moral and ethical wheat and chaff more restrictive than the minimal "living" must be arrived at and agreed upon.

O’Neill says that some philosophers have considered "rationality or potentiality for rationality (variously construed), and yet others... sentience or the ability to suffer" as possible keys to setting the scope for ethical consideration. ${ }^{10}$ Clearly viruses, bacteria, and plants fail these tests, so maybe that is the way out of the present morass for O'Neill.

\section{A Brief Interruption}

It should be clear by now that the discussion is well beyond the scope of O'Neill's program. It has been seen in the preceding cases that actions of agents are insufficient to give a coherent account of moral boundaries, and supplemental notions of rationality, sentience, consciousness, or some equally intractable philosophical concept to better set ethical lines of demarcation are sought. The need for supplementation is striking and must be viewed as a devastating problem for O'Neill.

\section{An Interruption of the Interruption}

It might be alleged here that O'Neill is being treated unfairly, that a definition of agency is sought when this is precisely what she denies is needed. In her discussion of plurality, the capacities to be affected by and to respond to activity seemed central to the notion of agency, but these cannot 
be understood to be sufficient for agency (though the capacity to be affected by actions is certainly necessary). A prisoner completely in the power of another may be incapable of responding to treatment from his captor, but he is surely owed ethical treatment. Dirt is affected by spades, rakes, and hoes when a gardener uses these implements. Flies respond to being swatted at by flying away, and plants respond to a curtain being partially drawn by turning their leaves toward the remaining sunlight. O'Neill doesn't therefore confer upon dirt, flies, and plants agency or otherhood, and it can't fairly be demanded that to respond to activity in the requisite ways requires consciousness. In fact, O'Neill specifically denies this. ${ }^{11}$ Instead, she explicitly requires that for the assumption of plurality to be adopted there be a recognition that there are others who may be affected by or respond to activity; that is to say, agency is prior to these capacities. To be even-handed, it may be claimed, the concept of agency must be accepted as a practical one - it is quite simply obvious to agents qua agents who or what counts as an other. Note, however, that if the otherhood-is-obvious plank is to be added to O'Neill's platform, a supplement is still required. Now actions alone cannot determine ethical scope - a proper attitude regarding others is also required.

\section{Back to the Story}

Jackson and Sims are two expectant mothers with unwanted pregnancies. Though Jackson is not promiscuous and took great care to not become pregnant, she is nonetheless with child. She is considering having an abortion. It is well known that very often such a procedure brings with it a great deal of guilt for the mother, and Jackson is just such a mother. She seeks counseling, consults with her family and minister, and finally goes through with the operation. She enters the clinic burdened by guilt and leaves it in the same fashion. Sims, on the other hand, is a libertine; she sleeps around and takes no precautions against pregnancy at all. She has had several abortions, all as means of birth control, and her activities have not changed in the least. She is completely irresponsible with regard to pregnancy, and feels entirely guiltless in aborting yet another fetus. She doesn't abort her unborn children because she is unable to care for them, because she has a heart condition that would endanger her life if she carried the child to term, or even because she would be inconvenienced. She just thinks that being pregnant and having something growing inside her is somehow "icky" - that's the only reason for her terminating all those pregnancies. Still, the question remains: Do the fetuses of Jackson and Sims deserve ethical treatment and moral consideration? Based on their actions and attitudes, do we conclude that Jackson's child is worthy of such consideration and Sims' is not? If so, this seems strange indeed. Why would two people (or, in Sims' view, mere fetuses) in the same position have different moral standings simply because one is involved with a more compassionate person than the other? Sims' actions clearly indicate that she has made no assumptions of the relevant kind regarding her unborn children, but 
Jackson's indicate that she has, and the actions of both women bear out their respective attitudes. How is it that Jackson's fetus is entitled to treatment Sims' baby does not deserve? This is just such a scenario envisioned by O'Neill, but she deals with it cryptically: "If some agents genuinely do not take certain others as agents, there will be no way to convince them that those others fall within the scope of their ethical consideration." 12 There are two possible readings of this passage, one plausible and one not. Context indicates that it is implausible to read O'Neill as saying that there is no way to convince an offender that ethical treatment is required of him towards his victim because the victim is truly not within his ethical scope. O'Neill may be read more reasonably as saying that although the victim is within the offender's moral scope, he will refuse to accept this.

What are we to make of this? We cannot take the earlier tack of claiming that the Sims, like the Nazis before, is being disingenuous when she denies that those she treats badly are within the bounds of her moral consideration - by hypothesis she is not being disingenuous. The only sensible way to interpret O'Neill's remark is to say she claims there is some extra-behavioral and extra-attitudinal work being done in these situations. This, however, is a move that undercuts her whole position - a position that claims ethical scope in Sims' case, and in fact in all cases, can be determined solely in terms of the behavior (and, again, the attitudes towards others) of Sims. Can O'Neill be claiming that ethical scope is determined by behavior of "most normal people" or determined by the way "most normal people" would behave if put in that position? Even ignoring the obvious problem of defining "normal human beings," this still proves troubling, since just a couple of centuries ago "most normal people" genuinely felt that the enslaving of Africans was an acceptable thing to do, morally speaking. It seems hard to believe that O'Neill would sign off on the idea that a behavior is moral until a critical mass of "normal people" declares it not to be so, thus moving the boundary of the moral scope.

There is one more possible route for O'Neill to take, but it, too, seems problematic. Maybe one could say that Sims' ethical scope does not include her fetuses only if she can tell us a compelling enough story to account for her actions in such a way that we are convinced that she, in fact, does not assume plurality, connection, and finitude toward her unborn children. This will not do, either. Her actions do not indicate that she has made these assumptions: There is nothing for her to explain away. It is only that her attitude seems so outrageous that one assumes that she is wrong in completely excluding her fetuses from her ethical scope. She may be wrong to do so, but only if we posit that her ethical scope is set by something other than her actions and attitudes. Sims genuinely doesn't feel her unborn baby is within her ethical scope, and her actions bear this out. Should we then declare that she is in error in assuming her fetus is not entitled to ethical treatment? Again, to do this we must assume that her ethical scope is determined by factors other than her actions. This, of course, is not a move available to O'Neill. 


\section{Summary}

O'Neill's practical approach to setting an ethical scope gets its genesis from two observations. The first is that all attempts to form a notion of agency or personhood on theoretical grounds have met with failure, the assumption in these theories being that only agents or persons may demand ethical consideration. Some systems, such as Aristotle's, do not count infants as persons; others, such as those of Singer and Kuhse, ${ }^{13}$ trying to remedy this shortcoming, cast too wide a net, capturing animals and even plants, while others, whose scope is more pleasing, draw arbitrary lines between agents and non-agents, persons and non-persons. The second observation is that actions speak louder than words. That is, we can tell more about what people really think by considering what they do rather than what they say. In this way it is easy to dispel the claims of genocidal groups who insist their victims are somehow less than human - but only if their actions bear this out, which is generally the case. In this regard O'Neill's approach is particularly effective.

O'Neill falls short, however, when she claims that the consideration solely of actions gives us a method to separate agents from non-agents in a systematic way. She says "[w] hat is assumed for purposes of activity must also be assumed in fixing the scope of ethical consideration," 14 but we have seen that some things which are clearly not entitled to ethical consideration (fires, viruses, and bacteria, for example) must be considered agents based on the activities of human beings. O'Neill also tells us that "[a] practical approach to moral standing claims only that what we assume in acting, we cannot selectively revoke in reaching moral judgments." 15 Therefore, we are not entitled to take, say, house fires off our list of agents for just any reason; there must be a compelling reason to do so. But to exclude these from our list of those for whom moral consideration is appropriate, we have found either that a metaphysical account of personhood is required or that we must concede that otherhood is a practical concept, and it's just clear to everyone what an other is. This, though, is plainly false. Any applied ethics textbook provides examples of different groups of people or things about which there is no consensus regarding how they should be treated.

Even worse for O'Neill, this implies, and she seemingly accepts, that there are those for whom her system will not work. Psychopaths who do not already see that their human victims deserve ethical treatment cannot be convinced otherwise, even though these humans are, in fact, within their ethical scope. But this scope cannot be determined by the actions and attitudes of these psychopaths alone, so her system is necessarily incomplete. Similarly, O'Neill's program often captures too much in its scope. If Smith really feels that house fires or viruses are others, then they are entitled to ethical treatment from him. More realistically, if Smith believes dogs are others and Jones does not, then, unless Smith consistently treats dogs badly, Smith owes dogs ethical treatment and Jones does not. As it stands, O'Neill's position seems to have as an uncomfortable implication the proposition that ethical treatment is owed to those to whom we think it is owed as long as we act 
in ways that entail we have made the assumptions of plurality, connection, and finitude (and it has been shown that this is not unusual even for those things we don't believe are others). Generally, then, animal lovers owe dogs, cats, and ferrets moral consideration while non-animal lovers do not. Any sense of universality is lost when we consider that in the United States dogs are thought to be suitable pets and are therefore more likely to be viewed as others while deer are not seen as suitable pets and are consequently not viewed as others by, say, deer hunters, but in other cultures dogs are often thought of as an evening meal. Evidently it is simply a case of bad luck for dogs to be born in the Far East rather than the United States and it is similarly unlucky for cows to be born in the U.S. rather than in India, for American dogs and Indian cows are deserving of justice while their counterparts in these two countries are due no such consideration. More disturbing, it's okay (ethically, if not legally) for Charles Whitman to pick off Texans from the University Tower in Austin simply because he has no sense of duty to other people while no such excuse exists for University of Oklahoma students merely upset at an unhappy conclusion to the annual Oklahoma-Texas football match-up. O'Neill may buttress her account by claiming that ethical scope is determined not by the actions and attitudes of individuals, but by how a majority of normal human beings would act and feel under the same constraints, but it has been shown how this will necessitate the evolution of ethical scope through time. Indeed, large majorities throughout history, even up to the present day, have tacitly and sometimes explicitly endorsed persecution and mass murder of some groups. If ethical behavior, even that governing just how we behave toward one another in everyday settings, is to have any universal flavor to it, and it seems that it must, this evolution of moral scope cannot be accepted. To avoid this, O'Neill may deny that her system is incomplete, but that entails accepting the rather odious conclusion that it is ethical for some people (Neo-Nazis, for example) to mistreat certain groups while it is unethical for other (more ethical?) groups to behave in precisely the same fashion.

It is to be taken, then, that O'Neill's system is either incomplete or flawed, and if incomplete, its satisfactory completion seems rather unlikely. Its greatest strength is in its ability to demonstrate that people who disingenuously and to their own advantage describe others as not deserving of moral consideration are not acting in an entirely honest manner. This in itself is a significant improvement on the existing body of literature regarding ethical scope and, thus, should not be overlooked or taken lightly. 


\section{Notes}

1. Onora O’Neill, Towards Justice and Virtue (New York: Cambridge University Press, 1996), 95.

2. Ibid, 96.

3. Ibid, 102.

4. Ibid, 102.

5. Onora O'Neill, "Distant Strangers, Moral Standing, and State Boundaries," Current Issues in Political Philosophy: Justice in Society and World Order, (1997): 125.

${ }^{6}$. Ibid: 125, her emphasis.

7. Onora O’Neill, Towards Justice, 97.

${ }^{8}$. Ibid, 111.

9. Onora O’Neill, “Distant Strangers:” 123.

${ }^{10}$. Ibid: 123.

11. Onora O’Neill, Towards Justice, 101

${ }^{12}$. Ibid, 110, n. 30, her emphasis.

${ }^{13}$. Ibid, 95 , n. 7.

${ }^{14}$. Ibid, 106, her emphasis.

${ }^{15}$. Onora O’Neill, “Distant Strangers:” 124, my emphasis. 


\section{References}

O’Neill, O. "Distant Strangers, Moral Standing, and State Boundaries." Current Issues in Political Philosophy: Justice in Society and World Order (1997), 119-132.

. Towards Justice and Virtue. New York: Cambridge University Press, 1996. 